\title{
The Use of Prophetic Communication and Religious Message as a Way to Prevent COVID-19 Outbreak in Palu City
}

\author{
http://dx.doi.org/10.25008/jkiski.v6i1.485
}

\author{
Muhammad Khairil $^{* 1}$, Raisa Alatas ${ }^{2}$, Dyah Fitria Kartika Sari ${ }^{3}$ \\ Department of Communication Science, Universitas Tadulako \\ Jl. Soekarno-Hatta Km. 9, Palu 94118 - Indonesia \\ Corresponding author: kkhairil@untad.ac.id
}

Submitted: March 11, 2021, Revised: April 15, 2021, Accepted: June 04, 2021

Accredited by Kemristekdikti No. 28/E/KPT/2019

\begin{abstract}
This study discusses prophetic communication in spreading religious messages for the Coronavirus (COVID-19) outbreak prevention in Palu, Indonesia. This study is based on qualitative research with a case study approach. This study will lead to a detailed and in-depth description of the problem regarding the condition according to what happened in the field. The case study conducted in this research took place in Alkhairaat Foundation of Palu, Central Sulawesi. To support existing data, researchers also made direct observations to the Alkhairaat Foundation. Religion is not only a guide but also a source of life. The function of religion is to regulate human life such as amidst the COVID-19 outbreak through the basis of the Qur'an and hadith. Qur'an and Hadith become the basis in the formation of religious messages that are assembled by the Ulamas through their social media. Public opinion is then filled with tendencies that lead to Islamic ideas and at the same time, there are rejections of it which portray acceptance of information to have positive and negative sides. Ulamas used social media such as Facebook, WhatsApp, and online news. Ulamas also coordinate with local government to unite the perceptions on how to face the COVID-19 that also happened in Palu. Ulamas perform their roles by conveying fatwas. The strong influence of an Ulama as a figure means that every word and deed can be a hold for the people. In this case, Ulamas should remain consistent with what was conveyed. Because the conveyed fatwa is not an individual fatwa but an institutionalized fatwa.
\end{abstract}

Keywords: COVID-19; da'wah communication; outbreak prevention; prophetic communication; ulama

\section{Introduction}

The world was horrified by the spread of COVID-19 that originated from Wuhan, China in early 2020 (Swart, 2020). The World Health Organization (WHO) had even declared the Coronavirus or COVID-19 as a pandemic (Swart, 2020; World Health Organization (WHO), 2020). Coronavirus had spread over countries with the latest positive confirmed updates of approximately 1 million people worldwide and has killed more than 50,000 people (Worldometer, 2020). A virus outbreak like COVID-19 is not the first thing that happened in the world (Fadli, 2020; Jarus, 2020).

There are Cholera that occurred in 18171823, HIV/AIDS that occurred in 1976 until now Hong Kong Flu (Centers for Disease Control and Prevention, National Center for Immunization and Respiratory Diseases (NCIRD), 2019), SARS to Ebola which occurred in 2014 to 2016 (Jarus, 2020). Coronavirus adds to the list of a series of deadly virus pandemics that have occurred in the world. 
COVID-19 can infect anyone of any age groups. Thus, humans have to follow the prevention and termination of the chain of the spread of COVID-19. One of many efforts made and selected to be the most effective way to break the chain of transmission is physical distancing and social distancing (Aziz, 2020; Jefferson et al., 2011; National Center for Immunization and Respiratory Diseases (NCIRD), Division of Viral Diseases, 2020). Social distancing forces everyone to carry out quarantine by limiting all social activities that come in contact with many people, implementing work from home program for government agencies, prohibiting long-distance travelling and even by not allowing to shake hands (Gómez-Ríos et al., 2020). This effort was carried out as a way to break the chain of the spread of the virus.

Social distancing and self-quarantine limits the society which in turn creates a dilemma for some people (De Vos, 2020; Fenichel, 2013; Prem et al., 2020). On the one hand, people need limit their mobility by staying at home. But on another hand, other dilemmas are also present when the community must work to fulfil their daily needs (Fenichel, 2013) The amount of fake news and hoaxes circulating in the community unsettle the public (Djalante et al., 2020). People who do selfquarantine only rely on social media and TV as their source of information. The increasing anxiety supported by the pressure from selfquarantine makes many people who receive information both chain messages from social media and Whatsapp groups process them as truth and share them with others (Djalante et al., 2020).

Unclear circumstances make messages disseminated through the media and Muslim Ulama (the guardians, transmitters and interpreters of religious knowledge in Islam) important to be taken calmly in a solid basis (Niam, 2020). The transmitters role of Ulama is seen in Indonesia which is carried out by religious leaders through television channels, social media to YouTube, or through Whatsapp groups with the intention of to spread religious messages, to calm and to create peace in the community (Rizkiansyah, 2020).

The application of social distancing not only affects the economic and social aspects but also changes the religious order (Damayanti \& Nursalikah, 2020; Fenichel, 2013). Many policies are then implemented by some religious communities in the world and Indonesia, for example, online da'wah (preaching) or perform worship from their respective homes (Damayanti \& Nursalikah, 2020). In one of the social media also circulated a video where the call to prayer (Adhan) which changes the call to prayer from inviting to pray at the mosque to pray at your home (Al Amir, 2020; Saputra, 2020; Widiyani, 2020). In Indonesia itself, the call to pray at home is also recommended to be done not only for five daily prayers (Shalat al-Fard) but also Friday prayers (Shalat al-Jumu'ah) that usually must be carried out at the mosque which replaced with midday prayers $(\mathrm{Duhr})$ at home (Majelis Ulama Indonesia (MUI), 2020). These policies and regulations are not necessarily accepted by the general public (CNN Indonesia, 2020). Many questioned the validity of the rules and how the Ulama viewed this.

One circular letter which was later issued, for example, is the Central Sulawesi Branch of Majlis Ulama Indonesia (MUI) decision on March $26^{\text {th }}, 2020$ which one of the main points is to do Shalat and prayers at home in certain regional areas where there is a plague threatening (following the results of the correct analysis by the authorities) and overall lockdown of the area. In reality, the call to prayer still echoed in mosques, as a sign of the entry of prayer time (MUI Kota Palu, 2020). The prayer at home policy is not a new thing which turned out to had happened in the era of the companions of the Prophet Muhammad where thunderstorms and muddy roads made it difficult for Muslims to do Congregational Prayer (Shalat al-Jama'ah) in the mosque (Widiyani, 2020). The call to pray at home is a consequence of having to change the sound of the call to prayer that originally invited prayer at the mosque to at home (Al Amir, 2020; Saputra, 2020). As narrated by Abdullah bin AlHarith:

\begin{abstract}
It was raining and muddy when Ibn Abbas was about to pray with us. When the muezzin who announced the call to prayer said Hayyaa 'Alas Salaah, Ibn Abbas said to turn it into As Shalaatu fir Rihaal (prayers at home). People looked at each other with shocked faces. Ibn Abbas said, this had been done in the time of someone better than himself (referring to the time of the Prophet Muhammad) and this was proven (Shahih Bukhari) (Al-Bukhārī, 2000; Panuntun, 2020; Widiyani, 2020).
\end{abstract}

The letter issued by the Majlis Ulama Indonesia (MUI) is a way to balance between the obligation to pray and the current conditions limited by the COVID-19 outbreak. Religious beliefs of a person in the way of worship 
depends on each individual. In some people, the call to prayer at home with a mosque around the environment sometimes creates a dilemma among the people based on the habit and beliefs about Congregational Prayer in the mosque. So when religious messages are attached as a basis for supporting policies made by the government, people will then review the policy. Especially if this had happened at the time of the Prophet Muhammad which in turn gave the community a clear picture. Religious messages created to support government policy and also to break the chain of the spread of the Coronavirus are quickly accepted by the public with the power of social media.

Coronavirus (COVID-19) that very quickly spreads in Indonesia, along with the spread of religious messages, is nothing but to strengthen the understanding to the private community that the spread of this virus is a serious thing (Rizkiansyah, 2020). One method that is recommended and has also been implemented by some people as an effort to prevent the spread of the Coronavirus is the quarantine method. This quarantine method was also carried out during the time of the Prophet Muhammad (Gensini, 2004; Mustinda, 2020) which nowadays also called the social distancing. $\mathrm{T}$

he quarantine or isolation model for people suffering from infectious diseases was once recommended by Rasulullah Sallallahu'alaihi Wasallam (Gensini, 2004; Mustinda, 2020; newvision, 2020). Outbreaks of infectious diseases had occurred in the time of the Prophet Muhammad. The plague was leprosy that was contagious and deadly before the cure was known. The Prophet Muhammad Shallallahu'alaihi Wasallam also once warned his people not to be near the area that was affected by the plague (Mustinda, 2020). Conversely, if you are in a place affected by an outbreak is prohibited to get out of the area. As narrated in the hadith:

If you hear of an outbreak of plague in a land, do not enter it; but if the plague breaks out in a place while you are in it, do not leave that place (Shahih Bukhari) (Mustinda, 2020; newvision, 2020).

Palu, the capital of Central Sulawesi province, is also not free from the Coronavirus outbreak which gave birth to unrest among the community to carry out the prayer (Shalat). Ulama from the Alkhairaat was one of the most awaited to explain the religious law that was issued to carry out worship amidst such a pandemic situation. Habib Saggaf Aljufri as the main chairman of Alkhairaat tried to spread supporting hadiths which state that it is not wrong to pray from home as a form of supporting the quarantine method with a video recording distributed by Whatsapp groups. The pandemic situation was responded quickly by the general chairman Alkhairaat and chairman of the Central Sulawesi branch of the Majlis Ulama Indonesia, Habib Ali Aljufri, in coordination with the central Majlis Ulama Indonesia to immediately issue fatwas. The religious messages spread during this pandemic eventually made the community return to the starting point of human nature per religious law to not touch, not eat illicit food (which turned out to be the beginning of the Coronavirus source) and not cause damage on earth.

The chain messages on social media about the prevention and spread of the Coronavirus is no longer solely about hygiene and healthy behaviour. Moreover, the majority of the people of Palu are Muslim who apply religious values in daily life, making the messages are not only solely about health but also the religious values contained in it can provide understanding and knowledge about prevention and spread of Coronavirus. The role of prophetic communication is very important not only for the people of Palu in particular but for the entire Muslim community in the world (Mustinda, 2020; Rizkiansyah, 2020)

\section{Theoretical Framework}

Social penetration is focused on the behaviour and motivation of individuals. Relationship development is governed by a complex arrangement of strengths that the relationship agent must be able to pass through (Littlejohn \& Foss, 2011). Openness to disclose intimate information must be based on trust (Morissan, 2014). Thus, if we want reciprocity in terms of openness then we must try to gain the trust of others and vice versa. Social penetration theory plays an important role in focusing our attention on the development of relationships (Littlejohn \& Foss, 2011).

However, this theory cannot provide a satisfactory explanation of the actual practice of relationships in actual daily life (Griffin, 2010). When the penetration process is divided into four parts, from the initial opening in conveying information to the stage of information received with all the pros and cons, it can be seen that the penetration process is fast at the start but slows down as fast as the tightly wrapped inner layer 
is achieved. Social exchange theories assume that we can accurately measure the gifts of various interactions and that we have a good understanding of choosing actions that will provide the best results (Littlejohn \& Foss, 2011; Morissan, 2014).

\section{Material and Methodology}

This study is based on qualitative research with a case study approach. The main problem raised in this study concerns prophetic communication in the spread of religious messages for the prevention and spread of the Coronavirus (COVID-19) in Palu. This study will lead to a detailed and in-depth description of the problem regarding the condition according to what happened in the field. A case study is a qualitative approach that examines real life, cases or various cases through detailed and in-depth data collection involving various sources of information or multiple sources of information such as observations, interviews, audiovisual material and documents from various reports (Creswell, 2015). The case study conducted in this research took place in Alkhairaat Foundation of Palu, Central Sulawesi. To support existing data, researchers also made direct observations to the Alkhairaat Foundation.

This study uses purposive sampling to obtain depth on the data (Moleong, 2002). The sample selection process is carried out on primary data sources (informants). The informants in this study are Islamic religious leaders in Palu and also members and chairman of the Central Sulawesi Branch of Majlis Ulama Indonesia. The in-depth interview process is one way of data collection in addition to the document study which focuses on messages circulating in the media and the messages distributed by Majlis Ulama Indonesia of Palu.

Data analysis in qualitative research begins by preparing and organizing data (text data such as transcripts and Central Sulawesi Branch of MUI circular letters) for analysis, then categorizing data through the process of coding and code summarizing, and finally presenting data in chart, table or discussion (Creswell, 2015). The data obtained in the field are in the form of direct observation. Collected data are validated with issues circulating in the media and clarified with the interviewees. The validated and clarified data are presented in the form of descriptions.

\section{Result and Discussion}

Spreading the religious values amid the COVID-19 outbreak is considered important based on the Shari'a conveyed by the Ulama which is something that must go hand in hand with the people who receive it (newvision, 2020). Religious messages began to occupy their position when many people shared messages of religious models or hadiths which showed the quarantine model of the Prophet Muhammad.

The words of an Ulama become a reference when some important decisions become critical in the current pandemic (Dwiastono, 2020; Ishom, 2020). Seeing this situation, the scholars made religious messages based on the hadith of the Prophet. The quarantine or isolation model for people suffering from infectious diseases was once recommended by Rasulullah Sallallahu'alaihi Wasallam. Outbreaks of infectious diseases had occurred in the time of the Prophet Muhammad where there was leprosy that was contagious and deadly before the cure was known. In a hadith, Rasulullah Shallallahu'alaihi Wasallam said: Don't you keep seeing people who have leprosy (Shahih Bukhari) (Afifiyah, 2020; AlBukhārī, 2000).

Habib Ali then also revealed another Hadith which said whoever eats garlic or onions should keep away from us - or our mosque - and stay at home. The Prophet said this was because the smell of garlic could bother and harm others. Muslims do not want to be infected and that includes the sign of faith. According to Habib Ali, when we love ourselves, thus we must love others. The advice and fatwah issued by Ulamas for the pandemic that is happening now are based on the pandemics occurred in the time of the Prophet Muhammad. One way that was done at that time, was to avoid places where there was an outbreak by conducting an independent quarantine which nowadays called social distancing.

Prophet Muhammad Shallallahu'alaihi Wasallam also once warned his people not to be near the area that was affected by the plague. Conversely, if you are in a place affected by an outbreak is prohibited to get out. As narrated in the following hadith: If you hear of an outbreak of plague in a land, do not enter it; but if the plague breaks out in a place while you are in it, do not leave that place (Shahih Bukhari) (AlBukhārī, 2000; Mustinda, 2020). In the time of the Prophet Muhammad, if there was an area or community infected with Tha'un disease, 
Rasulullah Shallallahu'alaihi Wasallam ordered to isolate or quarantine the infected in special isolation places, far from residential areas (Hashman, 2012). When isolated, the patient was examined in detail, then treated with strict monitoring. The patients may leave the isolation room when they were declared to be completely healed (Gray, 2010).

On the other hand, according to Habib Alwi, the function of religion to regulate human life in the world is including the plague. But we will get a different understanding from each different person. Some people deify their emotions and follow their egos and do not heed the words of an Ulama even though Ulamas are said to be the heir to the prophet. Sometimes some think religion is only a matter of the afterlife, even though in the afterlife there is no more religion. Thus, religion is needed in the world only.

In Qur'an itself Allah said; AlQur'anu syifaa-u linnas which translated to the Qur'an is medicine for humans because more illnesses presentations arise from thoughts and feelings. People reading the Qur'an becomes calm. Amidst the pandemic, the Qur'an in its comprehension is written, don't harm yourself (Al-Qur'an, 2014). Religion is not only a guide but also a source of life. Human actions are summarized in religion and human behaviour. Arriving at the bathroom is also the affairs of religion. The matter of sleeping, eating and health are all taught by religion. The Ulama went hand in hand with giving the fatwa but the decision still held by the authorities. Applying a clean and healthy lifestyle for health is stated in the Qur'an. Fatwas issued by Ulamas are not only the responsibility of the Ulamas but the responsibility of all of us. All fatwas issued by Ulama will not be meaningful if the government does not provide decisive action and work together to undergo the fatwa. Considering the diverse culture of Indonesian with various backgrounds or multiculturalism, not a few people of Palu who until now do not want to follow the issued fatwa, one of which is the replacement of Friday prayers (Shalat alJumu'ah) with the midday prayer (Duhr). There are still many people who hold Friday prayers in congregation amid this Coronavirus pandemic.

\section{Media as Vessel to Spread Religious Messages \\ The development of increasingly} sophisticated communication technology facilitates the massive spread of da'wah (preaching) (Ismail et al., 2018). If in the past religious preaching was only limited to mosques or prayer rooms, today's preaching is not so (Rusli, 2013). Everyone can preach wherever and whenever they want through platforms such as YouTube, Facebook, and WhatsApp (Prasetya, 2018). The form of preaching is varied, starting from video lectures or articles, status, and quotes (Ismail et al., 2018). Technological developments have been accompanied by a flood of information flow to every nook and cranny that a media can reach. People who used to be used to limited information, now receive unlimited information (Ismail et al., 2018). This causes social shock, cultural shock and personality shock (Littlejohn \& Foss, 2011).

Circulating issues in the community regarding the MUI's decision related to praying at home and no Friday prayers were twisted by some people with the issue of hadith that stated people will be declared as infidels if they did not perform congregation Friday prayers three times in the mosque (Kurniawan, 2020). Yet according to Habib Alwi, the hadith does not speak of one's disbelief but questions the faith. It is also not appropriate to do in a state of a pandemic such as the COVID-19 outbreak. Information that is circulating in the media more or less affect the community. As a country with a predominantly Muslim community, including Palu, what circulates in the media is more or less influential on society. More than a few people believe fake news and hoaxes, thus the Ulamas also play an active role in clarifying and encouraging the public to keep praying at home to avoid spreading the Coronavirus and help to break the chain of the spread of the Coronavirus.

Some informants stated that the media had been maximized in delivering religious messages related to the pandemic. But there are indeed some people who disagree with what the delivered messages. More than a few members of the community think that religion must be in the mosque, could not be changed because it has become a habit and people feel something is missing. Thus, people still carry out congregational prayers in the mosque. Even in some areas, many people are trying to jump over the fence of the mosque to continue to pray in congregation. By continuing to gather big groups of people, one of which is praying in congregation, without us knowing, The people who attend could be a carrier in spreading the Coronavirus. As Habib Ali explained, if we love ourselves, then love others. It is clear that when we become carriers 
in spreading the Coronavirus, we also endanger the lives of others because we unconsciously helped to spread the virus and will harm people with lower or weaker state of the immune system.

Islam is by far the most highlighted religion (Majdi, 2018). As a religion that used to be only a peripheral phenomenon, in the broad scope of society, Islam seemed to have become completely different. We don't want Islam to be a cornered religion. But in reality, it is only Islam as a group that affect in all respects; other religions appear to be mere spectators and a little withdrew from their popularity in the public sphere. Public opinion is then filled by tendencies that lead to Islamic ideas and at the same time, there is a rejection of it. The existence of mass media is very influential in people's lives. The mass media can form opinions and even change people's behaviour (Pineda \& Buendía, 2015). Along with that, the presence of the media carries positive as well as negative values.

Therefore, the majority of Ulamas use various methods both from widespread social media and direct delivery of information (Rusli, 2013). Habib Ali himself has also used the media such as Facebook status and Whatsapp status which widely responded by the followers. This depends again on the Ulama who know the demographic of their followers. For this reason, the contextualization of contemporary $d a^{\prime} w a h$ is a necessity. This means that da'wah is properly understood and not only limited to recitation and lectures in certain places but also must penetrate the virtual world by using the internet and other technological tools. Although $d a^{\prime}$ wah is the duty of every Muslim, trying to utilize figures amid important situations can have a positive influence on society. The created effects still have pros and cons but there is nothing wrong with conveying.

Religion says that one will get merit, by all the methods used by the Ulamas to convey the message not only just for the community but also to themselves. According to Habib Ali, We who deliver it must take care that we should not be classified as the kaburamaktan indallahi antakulu mala taf'alun (the wrath of God is upon people who say but he does not do it). Therefore, social media such as Facebook, WhatsApp, online news is used and even the Ulamas ask to hold a coordination meeting with the local government to unite the perception on how to face the COVID-19 outbreak in Palu which the Ulamas took their role by conveying fatwas.

If in the past $d a^{\prime}$ wah was limited to only one place or region, then this digital era of preaching transcended territorial boundaries. A religious preacher can be accepted throughout the world through social media. Through technological advances, social media can be utilized as a tool to convey messages of change to people and society. Because the figure of an Ulama has a strong influence, each word and deeds can be a hold of the people and no longer questions religious shari'a. Such a way can be utilized in the current Corona outbreak situation to create peace and calm in the community.

\section{Social Penetration Process of Religious Message \\ In the early stages of the Corona outbreak,} the Ulamas had the task of conveying. According to Habib Alwi, the task of Ulama was to convey, because the Ulama was the heir to the Prophet, Ulama's responsibility is only to deliver good and true information to the public which means also to remind people. According to some Ulamas, only good and true information can be conveyed to the people through the mass media, both printed and electronic. The Ulamas also remind the people to be extra careful amidst this pandemic. Ulamas are also quick to react by issuing tausiah and fatwas to maintain stability and general public's physical and mental health.

Pros and cons can not be avoided in the community. The process of receiving information is not necessarily acceptable, especially with regards to one's beliefs. But Ulamas do not necessarily issue baseless information. They refer to the verses of Qur'an and the hadiths which become guidelines for the basis in releasing information to the public. Ulamas remain consistent with what they said and may not change. Ulama, in this case, Habib Saggaf Aljufri as the chief chairman of Alkhairaat and prominent scholars in Palu, is providing forms of support related to circular letters by the government. Meanwhile, a conveyed fatwa is not an individual fatwa, but it is institutionalized and the fatwa institution itself in Majlis Ulama Indonesia (MUI).

The government also must take its role to create stabilization in the community. The government also needs to be prepared, because according to Habib Ali, the community who did not heed the fatwa cannot be a hundred per cent blamed for looking for their daily sustenance. Many members of the community are looking 
for sustenance in a day to day basis. Such example portrays the role of all communities and the government. This is the time we show responsibility to others amidst the COVID-19 pandemic in which economic state becomes unstable in every part of the society. Social, economic, health and religion aspects should go hand in hand to create stability amid this COVID-19 outbreak.

\section{Conclusion}

Religion is not only a guide but also a source of life. The function of religion is to regulate human life such as amidst the COVID19 outbreak through the basis of the Qur'an and hadith. Qur'an and Hadith become the basis in the formation of religious messages that are assembled by the Ulamas through their social media. Public opinion is then filled with tendencies that lead to Islamic ideas and at the same time, there is a rejection of it which portrays acceptance of information to have positive and negative sides. The existence of mass media is very influential in people's lives. The mass media can form opinions and even change people's behaviour. Along with that, the presence of the media carries positive as well as negative values. Therefore, most of the Ulamas have used it entirely both from social media or direct delivery of information as needed.

Ulamas used social media such as Facebook, WhatsApp, and online news. Ulamas also coordinate with local government to unite the perceptions on how to face the COVID-19 that also happened in Palu. Ulamas perform their roles by conveying fatwas. The strong influence of an Ulama as a figure means that every word and deed can be a hold for the people. In this case, Ulamas should remain consistent with what was conveyed. Because the conveyed fatwa is not an individual fatwa but an institutionalized fatwa.

\section{References}

Afifiyah, S. (2020, March 30). Pandemi Corona dan Kisah Wabah Penyakit Zaman Nabi. Tagar.Id. Pandemi Corona dan Kisah Wabah Penyakit Zaman Nabi

Al Amir, K. (2020, March 18). Coronavirus and the Adhan: When the muezzin said pray from home. Gulf News. https://gulfnews.com/uae/health/coronavirus -and-the-adhan-when-the-muezzin-saidpray-from-home-1.1584526142163

Al-Bukhārī, A. M. bin I. ibnu al-M. bin B. al-Ja'fī. (2000). Șahīh al-Bukhārī. Thoha Putra.

Al-Quran. (2014). Departemen Agama RI AlQuran Terjemah dan Tajwid.
Aziz, S. (2020, March 30). Why "physical distancing" is better than "social distancing."

https://www.aljazeera.com/news/2020/03/p hysical-distancing-social-distancing200330143325112.html

Centers for Disease Control and Prevention, National Center for Immunization and Respiratory Diseases (NCIRD). (2019, January 2). 1968 Pandemic (H3N2 virus). Central for Disease Control and Prevention $(C D C)$. https://www.cdc.gov/flu/pandemicresources/1968-pandemic.html

CNN Indonesia. (2020, April 18). Aceh Barat Izinkan Warga Tarawih di Masjid sebab Nihil Corona. CNN Indonesia. https://www.cnnindonesia.com/nasional/202 00418125713-20-494818/aceh-baratizinkan-warga-tarawih-di-masjid-sebabnihil-corona

Creswell, J. W. (2015). Penelitian Kualitatif dan Desain Riset (Ed Ke-3). Pustaka Pelajar.

Damayanti, I., \& Nursalikah, A. (2020, March 24). Wabah Covid-19 Ubah Cara Muslim Dunia Beribadah. Republika.Co.Id. https://republika.co.id/berita/q7ob52366/wa bah-covid19-ubah-cara-muslim-duniaberibadah

De Vos, J. (2020). The effect of COVID-19 and subsequent social distancing on travel behavior. Transportation Research Interdisciplinary Perspectives, 100121. https://doi.org/10.1016/j.trip.2020.100121

Djalante, R., Lassa, J., Setiamarga, D., Sudjatma, A., Indrawan, M., Haryanto, B., Mahfud, C., Sinapoy, M. S., Djalante, S., Rafliana, I., Gunawan, L. A., Surtiari, G. A. K., \& Warsilah, H. (2020). Review and analysis of current responses to COVID-19 in Indonesia: Period of January to March 2020. Progress in Disaster Science, 6, 100091. https://doi.org/10.1016/j.pdisas.2020.10009 1

Dwiastono, R. (2020, April 7). Peran Pemuka Agama Dianggap 'Strategis' di Tengah Pandemi Virus Corona. VOA Indonesia. $\mathrm{https}$ ://www.voaindonesia.com/a/peranpemuka-agama-dianggap-strategis-ditengah-pandemi-virus-corona/5362098.html

Fadli, dr. R. (2020, February 6). Selain Virus Corona, Ini 12 Wabah Mematikan Lainnya dalam Sejarah. Halodoc. https://www.halodoc.com/selain-viruscorona-ini-wabah-mematikan-lainnyadalam-sejarah

Fenichel, E. P. (2013). Economic considerations for social distancing and behavioral based policies during an epidemic. Journal of Health Economics, 32(2), 440-451. 
https://doi.org/10.1016/j.jhealeco.2013.01.0 02

Gensini, G. (2004). The concept of quarantine in history: From plague to SARS. Journal of Infection, 49(4), 257-261. https://doi.org/10.1016/j.jinf.2004.03.002

Gómez-Ríos, D., Ramirez-Malule, D., \& Ramirez-Malule, H. (2020). The effect of uncontrolled travelers and social distancing on the spread of novel coronavirus disease (COVID-19) in Colombia. Travel Medicine and Infectious Disease, 101699. https://doi.org/10.1016/j.tmaid.2020.101699

Gray, D. J. (2010). Rasulullah is My Doctor. Sinergi.

Griffin. (2010). A First Look at Communication Theory (8th Edition). McGraw Hill.Bungin.

Hashman, A. (2012). Rahasia Kesehatan Rasulullah: Meneladani Gaya Hidup Sehat Nabi Muhammad SAW. Noura Books.

Ishom, M. (2020, March 15). Perhatian Ulama terhadap Ilmu Kesehatan Terkait Corona. $N U$

Online. https://www.nu.or.id/post/read/117821/perh atian-ulama-terhadap-ilmu-kesehatanterkait-corona

Ismail, A. M., Mujani, W. K., \& A.M, A. A. Z. (2018). Methods of Da'wah and Social Networks in Dealing with Liberalism and Extremism. ISLAMIYYAT, 40(2).

Jarus, O. (2020, March 20). 20 of the worst epidemics and pandemics in history. Live Science.

https://www.livescience.com/worstepidemics-and-pandemics-in-history.html

Jefferson, T., Del Mar, C. B., Dooley, L., Ferroni, E., Al-Ansary, L. A., Bawazeer, G. A., van Driel, M. L., Nair, N. S., Jones, M. A., Thorning, S., \& Conly, J. M. (2011). Physical interventions to interrupt or reduce the spread of respiratory viruses. Cochrane Database of Systematic Reviews. https://doi.org/10.1002/14651858.CD00620 7.pub4

Kurniawan, A. (2020, April 3). Ini Hadits Rasulullah Seputar Meninggalkan Shalat Jumat Tiga Kali. NU Online. https://islam.nu.or.id/post/read/118620/inihadits-rasulullah-seputar-meninggalkanshalat-jumat-tiga-kali

Littlejohn, S. W., \& Foss, K. A. (2011). Theories of Human Communication (Tenth Edition). Wavelan Press inc.

Majdi, A. L. (2018). Epistemologi Islamic Origins Studies (Analisis Pergeseran Paradigma dari Tradisionalisme ke Revisionisme). Sekolah Pascasarjana UIN Syarif Hidayatullah.

Majelis Ulama Indonesia (MUI). (2020). Fatwa Majelis Ulama Indonesia Nomor: 14 Tahun
2020 Tentang Penyelenggaran Ibadah dalam Situasi Terjadi Wabah Covid-19. Majelis Ulama Indonesia (MUI). https://mui.or.id/berita/27674/fatwapenyelenggaraan-ibadah-dalam-situasiterjadi-wabah-covid-19/

Moleong, L. (2002). Metodologi Penelitian Kualitatif. PT. Remaja Rosdakarya.

Morissan. (2014). Teori Komunikasi Individu Hingga Massa. Kencana Prenadamedia Group.

MUI Kota Palu. (2020). Fatwa Majelis Ulama Indonesia (MUI) Kota Palu Nomor: 14 Tahun 2020 Tentang Penyelenggaran Ibadah dalam Situasi Terjadi Wabah Covid19. Majelis Ulama Indonesia (MUI) Kota Palu.

Mustinda, L. (2020, January 28). Virus Corona dan Metode Karantina ala Rasulullah yang Kini Terbukti. Detiknews. https://news.detik.com/berita/d4876671/virus-corona-dan-metodekarantina-ala-rasulullah-yang-kini-terbukti

National Center for Immunization and Respiratory Diseases (NCIRD), Division of Viral Diseases. (2020, April 4). Social Distancing, Quarantine, and Isolation. Central for Disease Control and Prevention (CDC).

https://www.cdc.gov/coronavirus/2019ncov/prevent-getting-sick/socialdistancing.html

newvision. (2020, March 17). Coronavirus - an Islamic perspective. Newvision. https://www.newvision.co.ug/new_vision/n ews/1516641/coronavirus-islamicperspective

Niam, A. M. (2020, March 15). Antara Corona, Ulama, dan Sains. NU Online. https://www.nu.or.id/post/read/117846/antar a-corona--ulama--dan-sains

Panuntun, R. Z. G. (2020, April 2). Dilema Shalat \#dirumahaja dari Perspektif Psikologis. BincangSyariah.Com.

https://bincangsyariah.com/kalam/dilemashalat-dirumahaja-dari-perspektifpsikologis/

Pineda, M., \& Buendía, G. M. (2015). Mass media and heterogeneous bounds of confidence in continuous opinion dynamics. Physica A: Statistical Mechanics and Its Applications, 420, 73-84. https://doi.org/10.1016/j.physa.2014.10.089

Prasetya, A. B. (2018). Islamic Religious Messages in Local Television Level. Proceedings of the International Conference on Media and Communication Studies (ICOMACS 2018). International Conference on Media and Communication Studies(ICOMACS 2018), Bandung, 
Indonesia. https://doi.org/10.2991/icomacs18.2018.70

Prem, K., Liu, Y., Russell, T. W., Kucharski, A. J., Eggo, R. M., Davies, N., Jit, M., Klepac, P., Flasche, S., Clifford, S., Pearson, C. A. B., Munday, J. D., Abbott, S., Gibbs, H., Rosello, A., Quilty, B. J., Jombart, T., Sun, F., Diamond, C., ... Hellewell, J. (2020). The effect of control strategies to reduce social mixing on outcomes of the COVID-19 epidemic in Wuhan, China: A modelling study. The Lancet Public Health, S2468266720300736.

https://doi.org/10.1016/S24682667(20)30073-6

Rizkiansyah, B. (2020, March 25). Peran Alim Ulama di Tengah Wabah Corona. KIBLAT. https:/www.kiblat.net/2020/03/25/peranalim-ulama-di-tengah-wabah-corona/

Rusli, N. (2013). Spiritualising New Media: The Use of Social Media for Da'wah Purposes within Indonesian Muslim Scholars. Jurnal Komunikasi Islam, 3(1).

Saputra, E. Y. (2020, March 15). Wabah Virus Corona, Masjid Kuwait Ubah Azan agar Salat di Rumah. Tempo.Co. https://dunia.tempo.co/read/1319863/wabah -virus-corona-masjid-kuwait-ubah-azanagar-salat-di-rumah

Swart, M. (2020, April 27). Timeline: How the new coronavirus spread. Aljazeera.Com. https://www.aljazeera.com/news/2020/01/ti meline-china-coronavirus-spread200126061554884.html

Widiyani, R. (2020, March 18). Kisah di Masa Rasulullah, Lafal Adzan Diubah dan Diminta Sholat di Rumah. Detik News. https://news.detik.com/berita/d4944302/kisah-di-masa-rasulullah-lafaladzan-diubah-dan-diminta-sholat-di-rumah

World Health Organization (WHO). (2020, March 11). Coronavirus disease (COVID-19) Pandemic. Munich Security Conference.

Worldometer. (2020, April 28). COVID-19 CORONAVIRUS PANDEMIC UPDATE. https:/www.worldometers.info/coronavirus/ Indonesia Nomor 21 Tahun 2020 (p. 8). SK No 022868.

Rochadi, D. (2016). Pemanfaatan Media Sosial Sebagai Strategi Public Relations Dalam Manajemen Krisis Konser Lady Gaga.

Sarah, S. (2016). Analisis Aktivitas Sosial Media Marketing Hijup Melalui Instagram Sebagai Salah Satu Strategi Marketing.

Solis, B. (2011). Engage!: the complete guide for brands and businesses to build, cultivate, and measure success in the new web. John Wiley \& Sons, Inc., Hoboken, New Jersey.
South, J. (2011). The Power of Real-time Social Media Marketing. In Journalism Studies (Vol. 12, Issue 5).

undaram, R., Sharma, R., Shakya, A. (2020). Power of digital marketing in building brands: A review of social media advertisement. International Journal of Management, 11(4), 244-254. https://doi.org/10.34218/IJM.11.4.2020.025

We Are Social \& Hootsuite. (2020). Indonesia Digital report 2020. Global Digital Insights, 247. https://datareportal.com/reports/digital2020-global-digital-overview

Young Living. (2018). About Young Living Essential Oils. Youngliving.Com.

Zaitseva, E. A., Srednyak, K. v., \& Kudryavtseva, M. E. (2019). SMM-tools in the Promotion of Small and Medium- Sized Business (In the Case of Nizhny Novgorod Market). Proceedings of the 2019 IEEE Communication Strategies in Digital Society Seminar, ComSDS 2019, 93-95. https://doi.org/10.1109/COMSDS.2019.870 9644 